\title{
SACRO-ILIITIS IN EIGHT POPULATIONS
}

\author{
BY \\ J. P. GOFTON, J. S. LAWRENCE, P. H. BENNETT, AND T. A. BURCH \\ From the Canadian Arthritis and Rheumatism Society, the Arthritis and Rheumatism Council Field Survey Unit, \\ and the National Institute of Arthritis and Metabolic Diseases, U.S.A.
}

In a preceding paper the high prevalence of ankylosing spondylitis in male Haidas was contrasted with estimates of the prevalence of this disease in other populations. The Haida prevalence was first discovered by a rough screening survey in 1962 (Robinson, Gofton, and Price, 1963). A subsequent study (Gofton, Robinson, and Trueman, 1966), specifically directed to this disease in 1964 , employed pelvic $x$ rays of all adult male respondents, and by this means almost twice as many cases of the disease were uncovered. It is possible that appraisals of this disease in other populations may have similarly underestimated the true prevalence. It is not certain, therefore, that a valid comparison can be drawn between these published estimates and the prevalence found in the Haidas.

Fortunately, a number of pelvic $x$ rays are available from previous population studies (Lawrence and Bennett, 1960; Bremner, 1961; Ansell and Lawrence, 1966; Lawrence, Bremner, Ball, and Burch, 1966). Using these films an attempt has been made to clarify this issue by a comparison of pelvic $x$ rays from several populations. This paper presents the results of this comparison.

\section{Method}

$X$ rays of the pelvis, from the populations shown in Table I, were brought by the three authors to the Clinical Field Studies Unit of the National Institutes of Health, Phoenix, Arizona, where facilities were kindly ${ }_{0}^{\circ}$ supplied by Dr. T. A. Burch, Director of the Unit ir Initially the three authors separately read and graded aln available films. $X$ rays read by any observer as abnorma $b$ were then removed and at a conjoint film-reading session? a mutually acceptable grade was established-described here as the "reconciled grading".

The evaluation of sacro-iliitis by $x$ ray, in this work, is restricted to the information found on a single antero. posterior view of the pelvis. Many films did not show any portion of the lumbar spine. To sustain compagare bility between the populations the interpretation was confined to changes in the sacro-iliac joints alone. These were graded according to the "Atlas of Standarb Radiographs" of the Rome Symposium (C.I.O.M:S.S 1963). Clinical data were not available and the Rome criteria for the diagnosis of ankylosing spondylitis werg్ not applied.

A full spectrum of age groups was not available for $a \vec{b}$ populations. The results are therefore shown by decades $₹$ to allow for appropriate comparison.

TABLE I

SAMPLING METHODS INCLUDING AGE DISTRIBUTION OF STUDY POPULATIONS

\begin{tabular}{|c|c|c|c|c|c|c|c|c|c|}
\hline \multirow{2}{*}{ Source } & \multirow{2}{*}{ Supplied by } & \multirow{2}{*}{ Sample } & \multicolumn{7}{|c|}{ Age Distribution of Respondents-All Males } \\
\hline & & & $15-24$ & $25-34$ & $35-44$ & $45-54$ & $55-64$ & $65+$ & Total \\
\hline Watford & Ansell and Lawrence, 1966 & Area & $\mathbf{0}$ & 20 & 14 & 28 & 23 & 13 & 98 \\
\hline Pima & Bennett & Native Resident on Reserve & $\mathbf{0}$ & 44 & 81 & 68 & 70 & 92 & 355 \\
\hline Blackfeet & Bennett & Native Resident on Reserve & 0 & 72 & 109 & 93 & 83 & 64 & 421 윽 \\
\hline Haida & Gofton & Native Resident on Reserve & 62 & 32 & 31 & 34 & 31 & 19 & 209 \\
\hline ASK* & Lawrence & Area* & 0 & 16 & 21 & 22 & 25 & 9 & 93 \\
\hline Wensleydale & Bremner, 1961 & Random Sample Households & $\mathbf{0}$ & $\mathbf{0}$ & $\mathbf{0}$ & $\mathbf{0}$ & 43 & 49 & 92 \\
\hline Leigh & Lawrence and Bennett, 1960 & Random Sample Households & $\mathbf{0}$ & 0 & $\mathbf{0}$ & $\mathbf{0}$ & 164 & 63 & 227 \\
\hline Jamaica & $\begin{array}{l}\text { Lawrence, Bremner, Ball, } \\
\text { and Burch, } 1966\end{array}$ & $\begin{array}{l}\text { Stratified Sample by Age and } \\
\text { Sex (Ages 35-64) }\end{array}$ & 0 & 0 & 86 & 83 & 86 & $\mathbf{0}$ & $255<$ \\
\hline
\end{tabular}

*ASK = ankylosing spondylitis kindreds. 1st degree relatives age $15+$ of patients with ankylosing spondylitis who attended Christie Hospitał, Manchester, in the years 1951-59 and who lived within 15 miles of the centre of Manchester. 


\section{Results}

Table I shows the source and age distribution of the population samples.

Table II shows a comparison between the populations for age groups over 25. Difficulty was experienced in interpretation of Grade 2 changes, producing the greatest measure of disagreement between the observers. For this reason a comparison has also been drawn between the populations for Grade 3 and 4 changes only.

Because the use of a "reconciled grading" is not entirely satisfactory in drawing comparisons between populations, individual gradings are shown and compared (Table III). The effect of discussion, and the reconciliation of opinions, was to lower the overall sensitivity of gradings, shown by a comparison between Table III and Table II. Most of the variation in grading concerned films read as minimal Grade 2 sacro-iliitis by one observer, and Grade 1 by the others-usually reconciled to Grade 1 after discussion.

It is interesting that significant differences in prevalence of sacro-iliitis are maintained, with one exception, in spite of the variations in sensitivity between the individual and reconciled grading.

TABLE II

$X$-RAY CHANGES IN SACRO-ILIAC JOINTS IN PERSONS AGED 25+-VARIOUS POPULATIONS COMPARED (Reconciled Grading. Three Observers)

\begin{tabular}{|c|c|c|c|c|c|c|c|c|}
\hline \multirow[t]{2}{*}{ Source } & \multirow[t]{2}{*}{$\begin{array}{c}\text { No. } \\
\text { Examined }\end{array}$} & \multicolumn{2}{|c|}{$\begin{array}{c}\text { Grade } \\
2,3 \text {, and } 4\end{array}$} & \multicolumn{3}{|c|}{ Grade } & \multicolumn{2}{|c|}{$\begin{array}{l}\text { Grade } \\
3 \text { and } 4\end{array}$} \\
\hline & & No. & Percentage & 2 & 3 & 4 & No. & Percentage \\
\hline Haida & 147 & 14 & $9 \cdot 5$ & 4 & 2 & $(1 \stackrel{8}{U})$ & 9 & $6 \cdot 1$ \\
\hline ASK & 93 & 9 & $9 \cdot 7$ & $(\stackrel{3}{1})$ & 4 & 2 & 6 & $6 \cdot 5$ \\
\hline Watford & 98 & 1 & $1 \cdot 0$ & 1 & 0 & 0 & 0 & 0 \\
\hline Blackfeet & 421 & 11 & $2 \cdot 6$ & $\left(3^{6} \mathbf{U}\right)$ & 4 & 1 & 5 & $1 \cdot 2$ \\
\hline Pima & 355 & 14 & $3 \cdot 9$ & $\stackrel{10}{(3 \mathrm{U})}$ & $\left(1^{3} \mathrm{U}\right)$ & 1 & 3 & 0.8 \\
\hline
\end{tabular}

Haida $v$ Watford-highly significant Blackfeet-highly significan Pima-significant

ASK $v$ Watford-highly significant Blackfeet-highly significant Pima-significant
Haida $v$ Watford-significant Blackfeet-highly significan Pima-highly significant

ASK $v$ Watford-significant Blackfeet-highly significan Pima-highly significant (significant $\quad=0.05>P>0.01$ ) (highly significant $=\mathbf{P}<0.01$ )

(U) $=$ Unilateral

TABLE III

$X$-RAY CHANGES IN SACRO-ILIAC JOINTS-VARIOUS POPULATIONS COMPARED (Three Observers-Individual Gradings Compared)

\begin{tabular}{|c|c|c|c|c|c|c|}
\hline \multicolumn{2}{|c|}{$\underset{\text { Grade }}{\text { Age 25 }}+$} & Haida & ASK & Watford & Blackfeet & Pima \\
\hline \multicolumn{2}{|c|}{ No. Examined } & 147 & 93 & 98 & 421 & 355 \\
\hline \multirow{4}{*}{ Percentages } & Reconciled Grade & $9 \cdot 5$ & $9 \cdot 7$ & $1 \cdot 0$ & $2 \cdot 6$ & $3 \cdot 9$ \\
\hline & Observer 1 & 17 & 12 & 0 & $4 \cdot 7$ & $5 \cdot 6$ \\
\hline & Observer 2 & 18 & 13 & 3 & $3 \cdot 3$ & $4 \cdot 2$ \\
\hline & Observer 3 & 13 & 12 & 2 & $4 \cdot 0$ & $8 \cdot 2$ \\
\hline
\end{tabular}

Observer 1

Haida/Watford-highly significant Haida/Blackfeet-highly significant Haida/Pima-highly significant

Observer 2

Haida/Watford-highly significant Haida/Blackfeet-highly significant Haida/Pima - highly significant

Observer 3 Haida/Watford-highly significant Haida/Blackfeet-highly significant Haida/Pima-not significant
ASK/Watford-highly significant ASK/Blackfeet-highly significant ASK/Pima-significant

ASK/Watford-significant ASK/Blackfeet-highly significant ASK/Pima - highly significant

ASK/Watford-highly significant ASK/Blackfeet-highly significant ASK/Pima-not significant 
The single anomaly between the individual and reconciled evaluations concerned the Haida/Pima comparison by Observer 3, who read a high proportion of Pima films as Grade 2 (24 of 29 abnormal films read as Grade 2). The Pima Indians have a high intake of fluorine because of the high concentrations of fluorine in wells used for drinking water. Throughout the pelvis of some Pima films marked sclerotic changes, typical of fluorosis, were seen. It is difficult, if not impossible, to distinguish sclerotic changes about the sacro-iliac joints due to fluorosis from the Grade 2 sacro-iliitis of ankylosing spondylitis (Møller and Gudjonsson, 1932), and it may be that the presence of significant fluorosis precludes a reliable grading of sacro-iliac joints for the sacro-iliitis of ankylosing spondylitis. No other population displayed this abnormality.

Table IV shows the full spectrum of sacro-iliitis in all populations, by decade age groups. Except for the comparison of ankylosing spondylitis kindreds (ASK) with Wensleydale, over the age of 55, major differences are found between the Haidas, or ankylosing spondylitis kindreds, and the other populations. The contrast between these groups and the Jamaica population is of exceptional interest.

Table V (opposite) shows the age-standardized rate, for sacro-iliitis, in the three North American Indian populations. A comparison between the observed rate and the age-standardized rate demonstrates that the differences between these populations are not attributable to differences in age groups between the samples.

\section{Discussion}

This study strengthens the comparisons between populations and supports the contention that an unusually high prevalence of ankylosing spondylitis exists among the Haidas. It also supports the view that this disease is more common in the relatives of $\stackrel{?}{\rightarrow}$ patients (ankylosing spondylitis kindreds). The? disease is probably rare in Jamaicans. It must be admitted, however, that completely satisfactory $\frac{\bar{\sigma}}{\overrightarrow{0}}$ comparisons between populations are so far lacking. $\stackrel{\unrhd}{\unrhd}$ The present study has certain shortcomings which $\cong$ should be stated.

Although all films were sorted together randomly it was $\overrightarrow{\vec{\omega}}$ not possible to exclude identifying features. A satis- $\sim$ factory "blind" reading could not be accomplished. Fortunately the population differences are large and this 0 imperfection is unlikely to be critical. Consideration of should be given, in future studies, to establishing an $\sigma^{\circ}$ acceptable standard of film size, technique, and film $\mathcal{N}^{-}$ marking so that the most valid comparisons can even- $\infty$ tually be made.

There was some variation in technical quality in the $\rightarrow$ films available for reading. A poor-quality film will $Z$ usually fail to show unequivocally clear sacro-iliac joint margins, and blurring is readily attributable to the $\frac{\Phi}{3}$ technical quality, a fact which tends to bias the interpreter towards under-grading such films. An early spondylitic, $\stackrel{\mathbb{C}}{-}$ otherwise gradable as 2 , is likely to be graded as 0 orol $\vec{c}$ through a technically poor film, leading to an undexestimation of the prevalence of the disease. A minimal standard of technical quality is of great importance in interpretation of sacro-iliac joint changes.

In an occasional case the appearance of the lower $\frac{\partial}{O}$ portion of the lumbar spine would have influenced the grading of sacro-iliac joints. As mentioned, the gradings $\mathbb{\Phi}$ here were confined to sacro-iliac joints alone and these $\underset{\vec{T}}{\stackrel{\Omega}{ }}$ 
- TABle V

AGE STANDARDIZED PREVALENCE RATES FOR SACRO-ILIITIS IN THE AMERICAN INDIAN POPULATIONS

\begin{tabular}{|c|c|c|c|c|}
\hline Grade & Populations & Respondents & $\begin{array}{c}\text { Observed Rate } \\
\text { (per cent.) }\end{array}$ & $\begin{array}{c}\text { Age-Standardized Rate } \\
\text { (per cent.) }\end{array}$ \\
\hline \multirow{3}{*}{2,3 , and 4} & Pima & 355 & $3 \cdot 9$ & $3 \cdot 85$ \\
\hline & Blackfeet & 421 & $2 \cdot 6$ & $2 \cdot 67$ \\
\hline & Haida & 147 & $9 \cdot 5$ & $9 \cdot 86$ \\
\hline \multirow{3}{*}{3 and 4} & Pima & 355 & $0 \cdot 8$ & $0 \cdot 79$ \\
\hline & Blackfeet & 421 & $1 \cdot 2$ & $1 \cdot 23$ \\
\hline & Haida & 147 & $6 \cdot 1$ & $6 \cdot 70$ \\
\hline
\end{tabular}

*Standardized by the indirect method to the age-specific prevalence rates for the combined population of the three tribes.

changes in the spine were ignored. Far-advanced changes of osteo-arthrosis in the lumbar spine might have influenced a difficult decision in the pelvis of an elderly subject where sacro-iliac joint sclerosis could be similarly explained. In the Pima Indians, fluorotic changes in the spine could have clarified an interpretation of sclerosis in the sacro-iliac joints. In the other direction, syndesmophytes in the lumbar spine may influence the interpretation of sacro-iliac joints showing minimal changes. A more satisfactory comparison of $x$ rays between populations would be possible if films of the dorso-lumbar spine were included.

Notwithstanding the shortcomings of this comparison, the large order differences between the populations described seem almost certain to be attributable to sacro-iliac changes characteristic of, and probably due to, what we know as ankylosing spondylitis.

It is unfortunate that family data are not available from the Haida study (Robinson and others, 1963).
It is known that the genetic pool of the Haida Indians contains a large admixture of white genes. On the other hand there is every reason to believe that the Haidas have the same general North American Indian derivation as the Blackfeet and Pima Indians. It seems unlikely that any relationship can be suspected between the racial origin of the Haida Indians and the increased prevalence of sacro-iliitis.

It is interesting that the prevalence of sacro-iliitis is approximately the same in the Haida Indians as in the male relatives of ankylosing spondylitis probands from England. The Haidas, now numbering some 1,200 persons, represent the condensation of a onetime population of 8,000 , two centuries ago. Some consanguinous marriages have certainly taken place. However, before the advent of the white men, the Haidas were accustomed to introducing new genetic material through raids on other Indian communities.

GES ALL AGES-BY DECADES

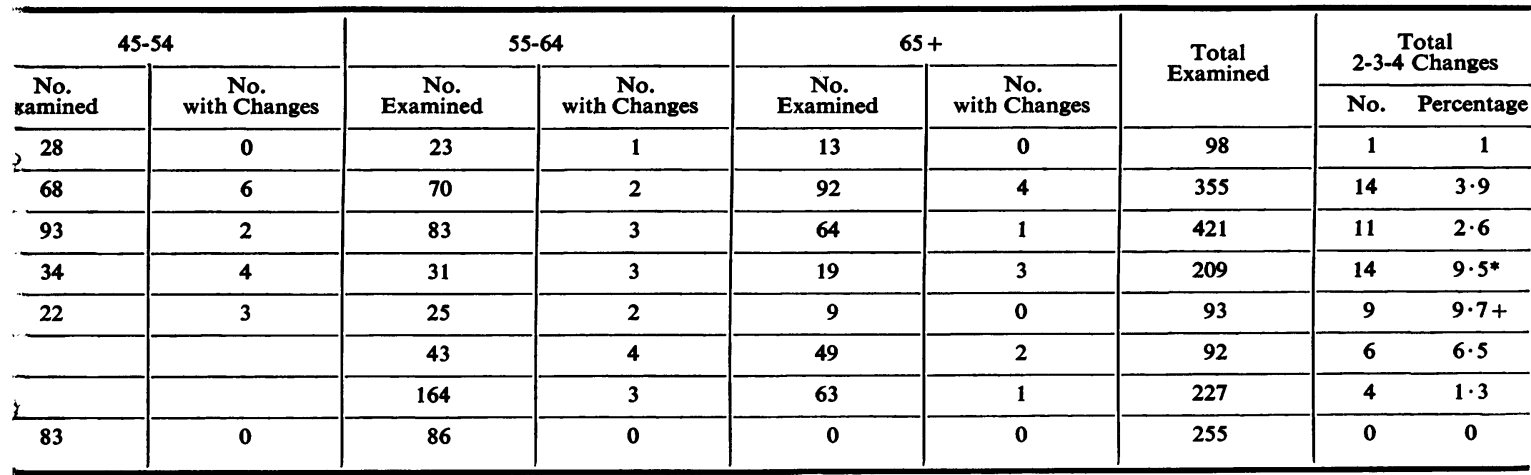


The equally high prevalence in these two groups has many implications, but the underlying meaning is so far obscure.

The only outstanding clinical characteristic of the disease in the Haidas, as seen on the survey, was the relative freedom from disability displayed by those afflicted. One man is severely crippled with disease in the hips, knees, and upper limbs. In the remainder the disease is confined to the spine and all have maintained good posture and function without having had any specific medical treatment directed towards prevention of disability. However, many of these showed $x$-ray changes of advanced ankylosis, often with typical changes in the lumbar spine. A previous publication describing the cases found by the screening survey (Robinson and others, 1963) indicated that there might be an unusual number of cases in the older age groups, with relative freedom from disease in men below the age of 40. This impression was not confirmed on the second study, the distribution of the disease extending throughout the age groups.

From the evidence available it is apparent that ankylosing spondylitis offers a fruitful field for further epidemiological studies. Although difficulties were encountered in applying the present Rome criteria to the Haidas, the criteria are generally valid and useful. In their present form they are useful tools for the evaluation of the prevalence of this disease in populations and are capable of defining differences of moderate degree or greater. It is probable that the differences so far defined are biologically meaningful. Further work may lead to an understanding of factors which contribute to the occurrence of the disease, and hopefully to an understanding of its aetiology.

\section{Summary}

1,750 pelvic $x$ rays of adult males from eight populations were compared for the presence of sacro-iliitis of the kind associated with classical ankylosing spondylitis. A high prevalence of these changes was considered to be present in the Haida Indian films and in those from first degree male relatives of patients with ankylosing spondylitis.
All other populations had significantly fewer changes. Methods of sampling, criteria used in film $\leftrightharpoons$ grading, and various methods of comparison are $\frac{D}{\omega}$ described. It is concluded that the Haida Indians have an inordinately high prevalence of sacro-iliitis, $\stackrel{\text { 足 }}{+}$ probably due to ankylosing spondylitis. When all? the populations are compared there would seem to $\frac{\bar{\sigma}}{\bar{\omega}}$ be geographical differences in the prevalence of $\bar{\alpha}$ ankylosing spondylitis.

\section{REFERENCES}

Ansell, B. M., and Lawrence, J. S. (1966). Ann. rheum. Dis., 25, 67.

Bremner, J. M. (1961). Ibid., $20,149$.

C.I.M.S. (1963) “The Epidemiology of Chronic Rheumatism", vol. 2. "Atlas of Standardo Radiographs of Arthritis". Blackwell, Oxford.

Gofton, J. P., Robinson, H. S., and Trueman, G. E.O (1966). Ann. rheum. Dis., 25, 525.

Lawrence, J. S., and Bennett, P. H. (1960). I Ibid., 19, 20. , Bremner, J. M., Ball, J., and Burch, T. A. (1966). Ibid., 25, 1.

Møller, P. F., and Gudjonsson, S. V. (1932). (Stockh.), 13, 269.

Robinson, H. S., Gofton, J. P., and Price, G. E. (1963) Ann. rheum. Dis., 22, 232.

\section{L'atteinte sacro-iliaque dans huit populations}

\section{RÉSUMÉ}

On a examiné 1750 radiographies de bassin des hommes adultes provenant de huit populations pour $\mathrm{y}$ rechercher là lésion sacro-iliaque du type associé à la spondylarthrite ankylosante. Une fréquence élevée de ces lésions fuß observée parmi les clichés des Indiens Haida et des pères? frères et fils de malades atteints de spondylarthrite ankylosante. On trouva significativement moins des telles lésions dans le reste des populations. On décrip. les méthodes d'échantillonage, les critères de classifica N tion des radiographies et de différentes méthodes dę comparaison. On est arrivé à la conclusion que l'atteintê sacro-iliaque chez les Indiens Haida est extraordinaire ment fréquente, ce qui est dû probablement à la spondye larthrite ankylosante. Lorsqu'on compare toutes les populations on trouve qu'il peut bien y avoir des différ ences géographiques dans la fréquence de la spondy larthrite ankylosante. 
Sacro-iliitis en ocho poblaciones

\section{SUMARIO}

Se hizo un estudio comparativo de 1750 radiografías de pelvis de varones adultos pertenecientes a ocho poblaciones para determinar la presencia de una lesión sacroiliaca del tipo encontrado en espondilartritis anquilosante clásica. Una incidencia elevada de estas alteraciones fué vista en las radiografías de los indios Haida y en varones cuyo parentesco con enfermos de espondilartritis anquilosante era de primer grado. En el resto de las poblaciones tales alteraciones fueron significativamente más escasas. Los metodos empleados en la selección de sujetos, los criterios de graduación de las radiografías y varios métodos de comparación son descritos. Se llegó a la conclusión de que los indios Haida tienen una incidencia extraordinaria de sacro-iliitis, probablemente debida a la espondilartritis anquilosante. Al comparar todas las poblaciones, diferencias geográficas en la incidencia de la espondilartritis anquilosante parece ser evidente. 